\title{
Retraction: GMO debate: inconclusive
}

\section{Frontiers in Genetics Editorial Office *}

*Correspondence: genetics.editorial.office@frontiersin.org

Approved by:

Richard A. Jorgensen, Carnegie Institution for Science, USA

\section{A retraction of the Opinion Article:}

GMO debate: inconclusive

by Dronamraju, K. (2013). Front. Genet. 4:123. doi: 10.3389/fgene.2013.00123

The journal wishes to retract the Opinion article cited above. Based on information reported after publication, this article was found to contain substantial sections that were taken verbatim from previous publications without proper quotation and citation.

The Journal and Chief Editor have decided to retract the article in its entirety and apologize to the readers of Frontiers in Genetics.

Received: 13 August 2013; accepted: 13 August 2013; published online: 20 August 2013.

Citation: Frontiers in Genetics Editorial Office (2013) Retraction: GMO debate: inconclusive.
Front. Genet. 4:169. doi: 10.3389/fgene. 2013.00169

This article was submitted to Plant Genetics and Genomics, a section of the journal Frontiers in Genetics. Copyright (c) 2013 Frontiers in Genetics Editorial Office. This is an open-access article distributed under the terms of the Creative Commons Attribution License (CC BY). The use, distribution or reproduction in other forums is permitted, provided the original author(s) or licensor are credited and that the original publication in this journal is cited, in accordance with accepted academic practice. No use, distribution or reproduction is permitted which does not comply with these terms. 